\title{
Aequorivita capsosiphonis sp. nov., isolated from the green alga Capsosiphon fulvescens, and emended description of the genus Aequorivita
}

Correspondence

Chi Nam Seong

scnu@scnu.ac.kr

\author{
Seong Chan Park, ${ }^{1}$ Keun Sik Baik, ${ }^{1}$ Mi Sun Kim, ${ }^{1}$ Seon Suk Kim, ${ }^{1}$ \\ Seok Ryel Kim, ${ }^{2}$ Myung-Joo Oh, ${ }^{2}$ Duwoon Kim, ${ }^{2}$ Byung-Ho Bang ${ }^{3}$ \\ and Chi Nam Seong ${ }^{1}$
}
${ }^{1}$ Department of Biological Sciences, College of Life Sciences and Natural Resources, Sunchon National University, Suncheon 540-742, Republic of Korea
${ }^{2}$ Division of Food Science and Aqualife Medicine, Chonnam National University, Yeosu 550-749, Republic of Korea
${ }^{3}$ Division of Food Sciences, College of Health Industry, Eulji University, Seongnam 461-713, Republic of Korea

\begin{abstract}
A marine bacterial strain, designated $A 71^{\top}$, was isolated from marine algae collected from the South Sea, Republic of Korea. Phylogenetic analysis based on 16S rRNA gene sequences indicated that strain $\mathrm{A} 71^{\top}$ belonged to the family Flavobacteriaceae and was closely related to Aequorivita antarctica SW49 ${ }^{\top}$ (96.5\% sequence similarity). Cells of strain $A 71^{\top}$ were Gramnegative, aerobic, oxidase-negative, catalase-positive, yellow/orange-pigmented and non-motile. The major fatty acids were iso- $\mathrm{C}_{15: 0}(20.6 \%)$, iso- $\mathrm{C}_{17: 1} \omega 9 c(13.3 \%)$, anteiso- $\mathrm{C}_{15: 0}(13.1 \%)$, iso- $\mathrm{C}_{17: 0} 3-\mathrm{OH}\left(12.7 \%\right.$ ) and summed feature 3 (comprising iso- $\mathrm{C}_{15: 0} 2-\mathrm{OH}$ and/or $\mathrm{C}_{16: 1} \omega 7 c$; $6.6 \%)$. The DNA G $+\mathrm{C}$ content was $36.9 \mathrm{~mol} \%$. Several phenotypic characteristics served to differentiate the isolate from recognized members of the genus Aequorivita. Data from this polyphasic study clearly demonstrated that strain $A 71^{\top}$ represents a novel species of the genus Aequorivita. The name Aequorivita capsosiphonis sp. nov. is proposed, with strain $\mathrm{A} 71^{\top}$ ( $=\mathrm{KCTC}$ $22183^{\top}=\mathrm{JCM} 15070^{\top}$ ) as the type strain. In addition, an emended description of the genus Aequorivita is presented.
\end{abstract}

Many members of the family Flavobacteriaceae are closely associated with living and dead components of the marine phytoplankton (Glöckner et al., 1999; Grossart, 1999; Brown \& Bowman, 2001). They can colonize living algae and absorb nutrient-containing exudates excreted by the host. In addition, they have an important role in the breakdown of complex dissolved and particulate organic matter in oceans (Cottrell \& Kirchman, 2000; Davey et al., 2001). The genus Aequorivita was recently described by Bowman \& Nichols (2002) as a novel member of the family Flavobacteriaceae. At the time of writing, the genus comprises four species: Aequorivita antarctica, A. lipolytica, A. crocea and A. sublithincola. A. sublithincola was isolated from a terrestrial cyanobacterial community in Antarctica, while the three other Aequorivita species were isolated from seawater. Members of the genus are characterized as

The GenBank/EMBL/DDBJ accession number for the $16 \mathrm{~S}$ rRNA gene sequence of strain $A 71^{\top}$ is EU290153.

Scanning electron and phase-contrast micrographs of cells of strain $\mathrm{A} 71^{\top}$ are available in a supplementary figure with the online version of this paper. psychrotolerant and non-agarolytic bacteria that are orange or yellow in colour (as a result of the presence of carotenoid pigments) (Bowman \& Nichols, 2002).

During the course of a study on the microflora of marine algae, a Gram-negative bacterium, designated strain $A 71^{\mathrm{T}}$, was isolated. A polyphasic approach was used to study this organism, which was found to have high levels of $16 \mathrm{~S}$ rRNA gene sequence similarity with respect to members of the genus Aequorivita. Here, our analysis of this novel member of the genus is described.

Strain $\mathrm{A} 71^{\mathrm{T}}$ was isolated from a sample of the green alga Capsosiphon fulvescens collected, in February 2006, from the South Sea near Yeosu $\left(34^{\circ} 44^{\prime} \mathrm{N} 127^{\circ} 44^{\prime} \mathrm{E}\right)$ located in the Republic of Korea, using the standard dilution plating technique. Isolation was achieved using MR2A [i.e. R2A agar (Difco) supplemented with $3.5 \%$ artificial sea salts (Sigma)]. The isolate was routinely cultured on marine 2216 agar (MA; Difco) at $25{ }^{\circ} \mathrm{C}$ and maintained at $-80{ }^{\circ} \mathrm{C}$ as a suspension in marine 2216 broth (MB; Difco) containing glycerol $(20 \%, \mathrm{w} / \mathrm{v})$. 
Bacterial DNA preparation, PCR amplification and sequencing of the 16S rRNA gene were carried out as described previously (Chun \& Goodfellow, 1995). The resulting sequence (1385 nt) was aligned manually against sequences obtained from the GenBank database. Phylogenetic trees were inferred from the regions available in all sequences (positions 39-1447; Escherichia coli numbering system) by using the Fitch-Margoliash (Fitch \& Margoliash, 1967) and neighbour-joining (Saitou \& Nei, 1987) methods. Evolutionary distance matrices were generated as described by Jukes \& Cantor (1969). The resultant neighbour-joining tree topology was evaluated by means of bootstrap analyses (Felsenstein, 1985) based on 1000 resamplings. Alignment and phylogenetic analyses were carried out using the jPHYDIT program (available at http://plaza.snu.ac.kr/ jchun/jphydit/) and PAUP 4.0 (Swofford, 2002) as described previously (Chun et al., 2000).

Preliminary sequence comparisons with 16S rRNA gene sequences held in GenBank indicated that strain $A 71^{\mathrm{T}}$ was closely related to the genus Aequorivita. The newly determined sequence was then aligned manually against representatives of the genus Aequorivita. Strain $\mathrm{A} 71^{\mathrm{T}}$ showed the highest 16S rRNA gene sequence similarity with A. antarctica SW $49^{\mathrm{T}}$ (96.5\%); the sequence similarities with respect to all other species of the genus Aequorivita were in the range 95.6-96.0\%. Also, strain A $71^{\mathrm{T}}$ occupied a distinct position in the neighbour-joining tree (Fig. 1). The tree based on the Fitch-Margoliash method showed essentially similar topology (not shown).

As the 16S rRNA gene sequence similarities between strain A $71^{\mathrm{T}}$ and strains of Aequorivita species with validly published names were below the level indicative of relatedness at the species level (97\%; Stackebrandt \& Goebel, 1994), a DNA-DNA hybridization test was not needed to define a novel species.

Cells grown for 5 days at $25{ }^{\circ} \mathrm{C}$ in $\mathrm{MB}$ were observed with phase-contrast (TMS-F; Nikon) and scanning electron (S4800; Hitachi) microscopy. Sea-salt requirements [final concentration $0-12 \%$ (Sigma), in increments of $1 \%$ ] and tolerance of $\mathrm{NaCl}(0-12 \%$, in increments of $1 \%)$ for growth were tested on nutrient agar (Difco), trypticase soy agar (Difco), R2A agar and ZoBell's agar (ZoBell, 1941; $5 \mathrm{~g}$ Bacto peptone, $1 \mathrm{~g}$ yeast extract, $0.1 \mathrm{~g}$ ferric citrate and $15 \mathrm{~g}$ Bacto agar, per litre distilled water). All of the media used in the physiological tests were supplemented with $2 \%$ sea salt, with the exception of MA and MB. The $\mathrm{pH}$ range for growth was determined in ZoBell's liquid medium. The media were adjusted to various $\mathrm{pH}$ values $(\mathrm{pH} 3-11$, in increments of $1 \mathrm{pH}$ unit) by the addition of $\mathrm{HCl}$ and $\mathrm{NaOH}$, which had been sterilized by filtration. Growth was tested (on MA after incubation for up to 1 week) at various temperatures $\left(4-50{ }^{\circ} \mathrm{C}\right)$ and in an anaerobic chamber $\left(\mathrm{CO}_{2} / \mathrm{H}_{2} / \mathrm{N}_{2}, 10: 10: 80\right.$; Sheldon Manufacturing). Catalase and oxidase activities were determined using $3 \%(\mathrm{v} / \mathrm{v})$ hydrogen peroxide and Kovács' reagent (Kovács, 1956), respectively. Acid production from glucose and maltose were tested as described by Yamaguchi \& Yokoe (2000). Nitrate reduction was tested in $\mathrm{MB}$ containing $0.2 \% \mathrm{KNO}_{3}$ (Skerman, 1967). $\mathrm{H}_{2} \mathrm{~S}$ production was determined on Kligler's iron agar (Difco). Hydrolysis of CM-cellulose $(1 \%, w / v)$, casein (2\% skimmed milk, w/v), dextran $(1 \%$, $\mathrm{w} / \mathrm{v})$, egg yolk $(10 \%, \mathrm{w} / \mathrm{v})$, elastin $(0.5 \%, \mathrm{w} / \mathrm{v})$, starch $(0.2 \%, \mathrm{w} / \mathrm{v})$ and Tween $80(1 \%, \mathrm{w} / \mathrm{v})$ was tested as described by Smibert \& Krieg (1994), using MA as the basal medium. Hydrolysis of L-tyrosine $(0.5 \%, \mathrm{w} / \mathrm{v})$ and xylan

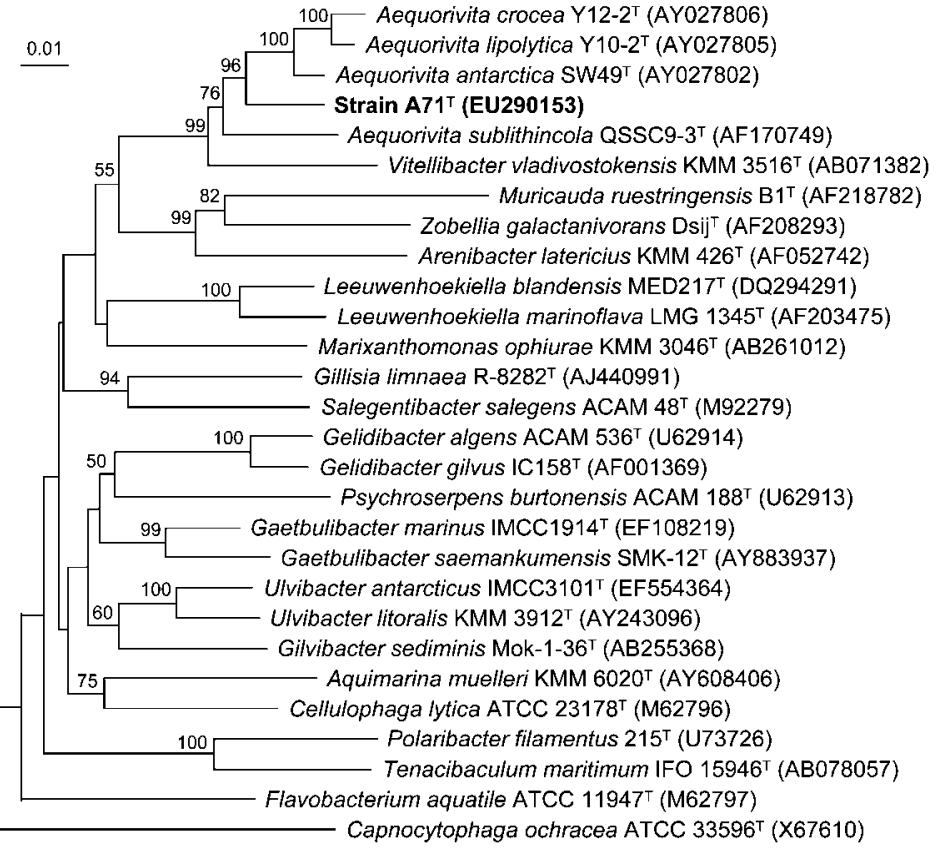

Fig. 1. Neighbour-joining tree phylogenetic tree, based on almost-complete 16S rRNA gene sequences, showing the relationships between strain $A 71^{\top}$ and members of the family Flavobacteriaceae. Numbers at nodes are bootstrap percentages (based on 1000 resampled datasets); only values greater than $50 \%$ are shown. The sequence of Capnocytophaga ochracea ATCC 33596 was used as an outgroup. Bar, 0.01 nucleotide substitutions per position. 
$(1 \%, w / v)$ was tested using $\mathrm{MA}$ as the basal medium (Barrow \& Feltham, 1993). Decomposition of xanthine $(0.4 \%$, w/v) was checked, using MA, as described by Gordon et al. (1974). DNase activity was determined on DNase test agar (Difco). Other biochemical tests and enzyme assays were performed using the API 20E and API ZYM kits (bioMérieux) and the GN2 MicroPlate (Biolog) according to the manufacturers' instructions except that bacterial strains were suspended in distilled water supplemented with $2 \%$ sea salt. Antibiotic resistance was determined using the disc-diffusion method, with commercial antibiotic-impregnated discs (BBL Becton Dickinson). After 5 days incubation at $25{ }^{\circ} \mathrm{C}$ on $\mathrm{MA}$, the results were interpreted according to the guidelines set forth by the CLSI (2003). The presence of flexirubin-type pigments was assessed as described by Bernardet et al. (2002).

Strain $A 71^{\mathrm{T}}$ grew well on MA and weakly on trypticase soy agar, but did not grow on R2A or nutrient agar without sea salt or $\mathrm{NaCl}$. Sea salt $(2-10 \%)$ supported growth of the cells on ZoBell's medium, but $\mathrm{NaCl}$ did not. Cells in $\mathrm{MB}$ were rod-shaped, but sometimes appeared to be filamentous or helical (Supplementary Fig. S1, available in IJSEM Online). On MA, colonies were yellow but turned orange after incubation for 6 days. Physiological characteristics are described in Table 1 and in the species description.

For fatty acid analysis, cells of strain $\mathrm{A} 71^{\mathrm{T}}$ grown on MA for 2 days at $20{ }^{\circ} \mathrm{C}$ were analysed using GLC according to the instructions of the Microbial Identification System (MIDI, 1999). The G+C content of the DNA was determined by using the thermal denaturation method of Marmur \& Doty (1962).

The fatty acid profiles of strain $A 71^{\mathrm{T}}$ and of the type strains of Aequorivita species with validly published names are shown in Table 2 . The predominant fatty acids of strain $A 71^{\mathrm{T}}$ were iso- $\mathrm{C}_{15: 0}$, iso- $\mathrm{C}_{17: 1} \omega 9 c$, anteiso- $\mathrm{C}_{15: 0}$, iso- $\mathrm{C}_{17: 0}$ $3-\mathrm{OH}$ and summed feature 3 (comprising iso- $\mathrm{C}_{15: 0} 2-\mathrm{OH}$ and/or $\mathrm{C}_{16: 1} \omega 7 c$ ). Fatty acids iso- $\mathrm{C}_{15: 1} \omega 10 c$, anteiso$\mathrm{C}_{15: 1} \omega 10 c$, iso- $\mathrm{C}_{16: 1} \omega 6 c$, anteiso- $\mathrm{C}_{17: 1} \omega 7 c$ and iso$\mathrm{C}_{17: 1} \omega 5 c$, found as major components in recognized Aequorivita species, were not detected in strain $\mathrm{A} 71^{\mathrm{T}}$ even though all strains were grown under the same conditions. However, the method used for the fatty acid analysis of strain $\mathrm{A} 71^{\mathrm{T}}$ differed from that used for the recognized Aequorivita strains. Fatty acids iso- $\mathrm{C}_{17: 1} \omega 9 c, \mathrm{C}_{17: 0} 2-\mathrm{OH}$ and iso- $\mathrm{C}_{15: 0} \mathrm{G}$ were found only in strain $\mathrm{A} 71^{\mathrm{T}}$. The DNA $\mathrm{G}+\mathrm{C}$ content of strain $\mathrm{A} 7 \mathrm{1}^{\mathrm{T}}$ was $36.9 \mathrm{~mol} \%$, a value that is within the range reported for Aequorivita species.

A number of phenotypic characteristics clearly distinguish strain $\mathrm{A} 71^{\mathrm{T}}$ from known Aequorivita species (Table 1). Therefore, strain $\mathrm{A} 71^{\mathrm{T}}$ represents a novel species within the genus Aequorivita, for which the name Aequorivita capsosiphonis sp. nov. is proposed. On the basis of new data from this study, an emended description of the genus Aequorivita is also proposed.
Table 1. Characteristics that serve to differentiate strain $A 71^{\top}$ from recognized Aequorivita species

Strains: $1, \mathrm{~A} 71^{\mathrm{T}} ; 2$, A. antarctica SW49 ${ }^{\mathrm{T}} ; 3$, A. lipolytica $\mathrm{Y} 10-2^{\mathrm{T}} ; 4$, A. crocea $\mathrm{Y} 12-2^{\mathrm{T}} ; 5$, A. sublithincola $9-3^{\mathrm{T}}$. Data for reference type strains are from Bowman \& Nichols (2002). All of the strains are positive for catalase and alkaline phosphatase activities and gelatin hydrolysis. All are negative for oxidase, arginine dihydrolase, lysine decarboxylase, ornithine decarboxylase, $\alpha$-fucosidase, $\alpha$-galactosidase, $\beta$-galactosidase, $\alpha$-glucosidase, $\beta$-glucosidase and $\beta$-glucuronidase activities and for hydrolysis of agar, CM-cellulose, dextran, xanthine and xylan. +, Positive; -, negative.

\begin{tabular}{|c|c|c|c|c|c|}
\hline Characteristic & 1 & 2 & 3 & 4 & 5 \\
\hline $\mathrm{Na}^{+}$ion requirement & + & + & + & - & + \\
\hline \multicolumn{6}{|l|}{ Hydrolysis of: } \\
\hline Aesculin & - & + & + & + & - \\
\hline Casein & + & - & + & + & - \\
\hline DNA & - & - & - & + & - \\
\hline Egg yolk & - & - & + & - & - \\
\hline Elastin & - & - & + & + & - \\
\hline Starch & - & + & - & - & - \\
\hline Tween 80 & - & + & + & + & + \\
\hline L-Tyrosine & - & + & + & + & + \\
\hline Urea & - & - & + & - & + \\
\hline \multicolumn{6}{|l|}{ Utilization of carbon sources } \\
\hline Glucose & - & + & + & + & - \\
\hline D-Lactose & + & - & - & - & - \\
\hline D-Sorbitol & + & - & - & - & - \\
\hline Sucrose & + & - & - & - & - \\
\hline $\begin{array}{l}N \text {-Acetyl- } \beta \text {-glucosaminidase (API } \\
\text { ZYM) }\end{array}$ & - & - & - & - & + \\
\hline DNA G $+C$ content $(\mathrm{mol} \%)$ & 36.9 & 38.5 & 35.6 & 33.8 & 36.5 \\
\hline
\end{tabular}

\section{Emended description of Aequorivita Bowman and Nichols 2002}

The description of the genus Aequorivita remains as given by Bowman \& Nichols (2002), with the following modifications. Oxidase-negative (this study; J. Bowman, personal communication). Filamentous or helical cells may occur in some species. Some species grow between 4 and $40{ }^{\circ} \mathrm{C}$ : optimal growth occurs at approximately $25{ }^{\circ} \mathrm{C}$. The major fatty acids are anteiso- $\mathrm{C}_{15: 0}$ and iso- $\mathrm{C}_{15: 0}$. The DNA $\mathrm{G}+\mathrm{C}$ contents are in the range $33.5-39.1 \mathrm{~mol} \%$.

\section{Description of Aequorivita capsosiphonis sp. nov.}

Aequorivita capsosiphonis (cap.so.si.pho' nis. N.L. gen. n. capsosiphonis of Capsosiphon, the scientific name of the marine alga from which the type strain was isolated).

Gram-negative, strictly aerobic bacterium. Oxidase-negative, catalase-positive and non-motile. In $\mathrm{MB}$, cells are rodshaped and $0.3-0.4 \times 2.0-3.0 \mu \mathrm{m}$ in size. In $\mathrm{MB}$, cells sometimes appear filamentous or helical and reach up to $15 \mu \mathrm{m}$ in size. Produces non-diffusible yellow- to orangecoloured pigments that are not of the flexirubin type. On MA, colonies are opaque, convex, circular, smooth and 
Table 2. Fatty acid compositions (\%) of strain $A 71^{\top}$ and type strains of recognized Aequorivita species

Strains: $1, \mathrm{~A}_{71}^{\mathrm{T}} ; 2$, A. antarctica SW49 $9^{\mathrm{T}} ; 3$, A. lipolytica $\mathrm{Y} 10-2^{\mathrm{T}} ; 4$, A. crocea $\mathrm{Y} 12-2^{\mathrm{T}} ; 5$, A. sublithincola $9-3^{\mathrm{T}}$. Data for reference type strains are from Bowman \& Nichols (2002). Fatty acids amounting to less than $1 \%$ of the total fatty acids in all strains listed are not shown. All strains were grown under the same conditions, but different methods were used for the fatty acid analyses. tr, Trace amount $(<1 \%) ;-$, not detected.

\begin{tabular}{|c|c|c|c|c|c|}
\hline Fatty acid & 1 & 2 & 3 & 4 & 5 \\
\hline $\mathrm{C}_{15: 0}$ & $\operatorname{tr}$ & $\operatorname{tr}$ & $\operatorname{tr}$ & $\operatorname{tr}$ & 3.1 \\
\hline $\mathrm{C}_{16: 0}$ & 3.9 & 1.9 & 1.2 & 2.9 & $\operatorname{tr}$ \\
\hline $\mathrm{C}_{18: 0}$ & 2.8 & - & - & - & - \\
\hline $\mathrm{C}_{15: 0} 2-\mathrm{OH}$ & 1.5 & - & - & - & - \\
\hline $\mathrm{C}_{17: 0} 2-\mathrm{OH}$ & 5.3 & - & - & - & - \\
\hline iso- $\mathrm{C}_{15: 0}$ & 20.6 & 7.6 & 16.3 & 15.9 & 16.8 \\
\hline anteiso- $\mathrm{C}_{15: 0}$ & 13.1 & 15.7 & 20.7 & 19.2 & 17.8 \\
\hline iso- $\mathrm{C}_{15: 0} 3-\mathrm{OH}$ & 1.5 & 5.4 & 1.7 & 2.9 & 2.1 \\
\hline anteiso- $\mathrm{C}_{15: 0} 3-\mathrm{OH}$ & - & 5.8 & 1.6 & 1.6 & $\operatorname{tr}$ \\
\hline iso- $\mathrm{C}_{16: 0}$ & 3.3 & 1.4 & 1.2 & 4.7 & 5.3 \\
\hline iso- $\mathrm{C}_{16: 0} 3-\mathrm{OH}$ & 1.6 & 9.2 & 2.1 & 4.4 & 5.6 \\
\hline iso- $\mathrm{C}_{17: 0} 3-\mathrm{OH}$ & 12.7 & 2.0 & 2.3 & - & 4.5 \\
\hline anteiso- $\mathrm{C}_{17: 0} 3-\mathrm{OH}$ & - & 2.9 & - & 4.2 & 4.0 \\
\hline iso- $\mathrm{C}_{15: 1} \omega 10 c$ & - & 9.5 & 10.5 & 8.9 & 12.9 \\
\hline anteiso- $\mathrm{C}_{15: 1} \omega 10 c$ & - & 16.0 & 23.0 & 13.8 & 8.5 \\
\hline iso- $\mathrm{C}_{15: 1} \mathrm{G}$ & 5.0 & - & - & - & - \\
\hline iso- $\mathrm{C}_{16: 1} \omega 6 c$ & - & 3.0 & 7.4 & 6.2 & 6.7 \\
\hline iso- $\mathrm{C}_{16: 1} \mathrm{H}$ & 1.0 & - & - & - & - \\
\hline iso- $\mathrm{C}_{17: 1} \omega 5 c$ & - & 5.8 & 4.8 & 8.6 & 9.7 \\
\hline iso- $\mathrm{C}_{17: 1} \omega 9 c$ & 13.3 & - & - & - & - \\
\hline anteiso- $\mathrm{C}_{17: 1} \omega 7 c$ & - & 5 & 4.2 & 3.2 & 2.5 \\
\hline anteiso- $\mathrm{C}_{17: 1} \omega 9 c$ & 2.0 & - & - & - & - \\
\hline $\mathrm{C}_{16: 1} \omega 7 c$ & - & 7.8 & 1.2 & 2.9 & $\operatorname{tr}$ \\
\hline Summed feature $3^{*}$ & 6.6 & - & - & - & - \\
\hline
\end{tabular}

${ }^{\star}$ Summed features are groups of two or three fatty acids that cannot be separated by GLC with the Microbial Identification System. Summed feature 3 consists of $\mathrm{C}_{16: 1} \omega 7 c$ and/or iso- $\mathrm{C}_{15: 0} 2-\mathrm{OH}$.

approximately $2 \mathrm{~mm}$ in diameter after 5 days at $25{ }^{\circ} \mathrm{C}$ (pH 7). Growth occurs at $\mathrm{pH} 7-9$ (optimum, $\mathrm{pH} 7$ ) and at $4-40{ }^{\circ} \mathrm{C}$ (optimum, $25{ }^{\circ} \mathrm{C}$ ). Requires sodium ions (at least $0.5 \% \mathrm{NaCl})$. Tolerates $8 \% \mathrm{NaCl}$ and grows weakly in the presence of $10 \% \mathrm{NaCl}$ on $\mathrm{R} 2 \mathrm{~A}$ agar and trypticase soy agar. Does not produce indole (API 20E). A positive reaction is obtained for $\mathrm{H}_{2} \mathrm{~S}$ production in the API $20 \mathrm{E}$ gallery, but no $\mathrm{H}_{2} \mathrm{~S}$ is detected on Kligler's iron agar. Acid is not produced from D-glucose or maltose (each at $0.5 \%, \mathrm{w} / \mathrm{v})$. Nitrate is not reduced. Produces acetoin (API 20E). Gelatin is hydrolysed, but aesculin, agar, CM-cellulose, casein, dextran, DNA, egg yolk, starch, Tween 80, tyrosine, xanthine and xylan are not hydrolysed. In the API ZYM gallery, alkaline phosphatase, acid phosphatase, esterase (C4), esterase lipase (C8), leucine arylamidase, naphtholAS-BI-phosphohydrolase and valine arylamidase activities are present, weak cystine arylamidase activity is detected and $N$-acetyl- $\beta$-glucosaminidase, $\alpha$-chymotrypsin, $\alpha$-fucosidase, $\alpha$-galactosidase, $\beta$-galactosidase, $\alpha$-glucosidase, $\beta$ glucosidase, $\beta$-glucuronidase, lipase (C14), $\alpha$-mannosidase and trypsin activities are absent. In the API $20 \mathrm{E}$ system, amygdalin, arabinose, glucose, inositol, mannitol, melibiose, rhamnose, sorbitol and sucrose are not assimilated. The following substrates in the GN2 MicroPlate gallery are utilized: L-aspartic acid, L-fucose, gentiobiose, D-glucosaminic acid, glycogen, inosine, $\alpha$-ketoglutaric acid and Lthreonine. The following substrates in the GN2 MicroPlate gallery are utilized only weakly: adonitol, L-alanine, Lasparagine, citric acid, D-galactonic acid lactone, DL-lactic acid, malonic acid, propionic acid, raffinose, turanose and uridine. The remaining substrates in the GN2 MicroPlate gallery are not utilized. Sensitive to the following antibiotics ( $\mu \mathrm{g}$ per disc, unless otherwise indicated): ampicillin (10), chloramphenicol (30), erythromycin (15), nalidixic acid (30), penicillin (10 IU), streptomycin (10) and vancomycin (30). Resistant to the following antibiotics ( $\mu \mathrm{g}$ per disc, unless otherwise indicated): amikacin (30), gentamicin (10), kanamycin (30), polymyxin B (300 IU) and tetracycline (30). The predominant fatty acids are iso$\mathrm{C}_{15: 0}$, iso- $\mathrm{C}_{17: 1} \omega 9 c$, anteiso- $\mathrm{C}_{15: 0}$, iso- $\mathrm{C}_{17: 0} 3-\mathrm{OH}$ and summed feature 3 (comprising iso- $\mathrm{C}_{15: 0} 2-\mathrm{OH}$ and/or $\mathrm{C}_{16: 1}(\omega 7 c)$. The DNA $\mathrm{G}+\mathrm{C}$ content of the type strain is $36.9 \mathrm{~mol} \%$. Other physiological and biochemical characteristics are given in Tables 1 and 2.

The type strain, $\mathrm{A}^{2} 1^{\mathrm{T}}\left(=\mathrm{KCTC} 22183^{\mathrm{T}}=\mathrm{JCM} 15070^{\mathrm{T}}\right)$, was isolated from Capsosiphon fulvescens, a green alga collected from the South Sea, Republic of Korea.

\section{Acknowledgements}

This work was supported by the 21C Frontier Microbial Genomics and Applications Center Program, Ministry of Education, Science and Technology, Republic of Korea.

\section{References}

Barrow, G. I. \& Feltham, R. K. A. (1993). Cowan and Steel's Manual for the Identification of Medical Bacteria, 3rd edn. Cambridge: Cambridge University Press.

Bernardet, J.-F., Nakagawa, Y. \& Holmes, B. (2002). Proposed minimal standards for describing new taxa of the family Flavobacteriaceae and emended description of the family. Int J Syst Evol Microbiol 52, 1049-1070.

Bowman, J. P. \& Nichols, D. S. (2002). Aequorivita gen. nov., a member of the family Flavobacteriaceae isolated from terrestrial and marine Antarctic habitats. Int J Syst Evol Microbiol 52, 1533-1541.

Brown, M. V. \& Bowman, J. P. (2001). A molecular phylogenetic survey of sea-ice microbial communities (SIMCO). FEMS Microbiol Ecol 35, 267-275.

Chun, J. \& Goodfellow, M. (1995). A phylogenetic analysis of the genus Nocardia with $16 \mathrm{~S}$ rRNA gene sequences. Int J Syst Bacteriol 45, 240-245.

Chun, J., Bae, K. S., Moon, E. Y., Jung, S. O., Lee, H. K. \& Kim, S. J. (2000). Nocardiopsis kunsanensis sp. nov., a moderately halophilic actinomycete isolated from a saltern. Int J Syst Evol Microbiol 50, 1909-1913. 
CLSI (2003). Performance standards for antimicrobial disk susceptibility tests, 8th edn. Approved Standard M2-A8. Wayne, PA: Clinical Laboratory Standards Institute.

Cottrell, M. T. \& Kirchman, D. L. (2000). Natural assemblages of marine proteobacteria and members of the Cytophaga-Flavobacter cluster consuming low- and high-molecular-weight dissolved organic matter. Appl Environ Microbiol 66, 1692-1697.

Davey, K. E., Kirby, R. R., Turley, C. M., Weightman, A. J. \& Fry, J. C. (2001). Depth variation of bacterial extracellular enzyme activity and population diversity in the northeastern North Atlantic Ocean. Deep Sea Res Part II 48, 1003-1017.

Felsenstein, J. (1985). Confidence limits on phylogenies: an approach using the bootstrap. Evolution 39, 783-791.

Fitch, W. M. \& Margoliash, E. (1967). Construction of phylogenetic trees. Science 155, 279-284.

Glöckner, F. O., Fuchs, B. M. \& Amann, R. (1999). Bacterioplankton compositions of lakes and oceans: a first comparison based on fluorescence in situ hybridization. Appl Environ Microbiol 65, 3721-3726.

Gordon, R. E., Barnett, D. A., Handerhan, J. E. \& Pang, C. H.-N. (1974). Nocardia coeliaca, Nocardia autotrophica, and the nocardin strain. Int J Syst Bacteriol 24, 54-63.

Grossart, H. P. (1999). Interactions between marine bacteria and axenic diatoms (Cylindrotheca fusiformis, Nitzschia laevis, and Thalassiosira weissflogii) incubated under various conditions in the lab. Aquat Microb Ecol 19, 1-11.

Jukes, T. H. \& Cantor, C. R. (1969). Evolution of protein molecules. In Mammalian Protein Metabolism, vol. 3, pp. 21-132. Edited by H. N. Munro. New York: Academic Press.
Kovács, N. (1956). Identification of Pseudomonas pyocyanea by the oxidase reaction. Nature 178, 703.

Marmur, J. \& Doty, P. (1962). Determination of the base composition of deoxyribonucleic acid from its thermal denaturation temperature. $J$ Mol Biol 5, 109-118.

MIDI (1999). Sherlock Microbial Identification System Operating Manual, version 3.0. Newark, DE: MIDI, Inc.

Saitou, N. \& Nei, M. (1987). The neighbor-joining method: a new method for reconstructing phylogenetic trees. Mol Biol Evol 4, 406425.

Skerman, V. B. D. (1967). A Guide to the Identification of the Genera of Bacteria, 2nd edn. Baltimore: Williams \& Wilkins.

Smibert, R. M. \& Krieg, N. R. (1994). Phenotypic characterization. In Methods for General and Molecular Bacteriology, pp. 607-654. Edited by P. Gerhardt, R. G. E. Murray, W. A. Wood \& N. R. Krieg. Washington, DC: American Society for Microbiology.

Stackebrandt, E. \& Goebel, B. M. (1994). Taxonomic note: a place for DNA-DNA reassociation and $16 \mathrm{~S}$ rRNA sequence analysis in the present species definition in bacteriology. Int J Syst Bacteriol 44, 846849.

Swofford, D. L. (2002). PAUP*: Phylogenetic analysis using parsimony (and other methods), version 4. Sunderland, MA: Sinauer Associates.

Yamaguchi, S. \& Yokoe, M. (2000). A novel protein-deamidating enzyme from Chryseobacterium proteolyticum sp. nov., a newly isolated bacterium from soil. Appl Environ Microbiol 66, 3337-3343.

ZoBell, C. E. (1941). Studies on marine bacteria. I. The cultural requirements of heterotrophic aerobes. J Mar Res 4, 42-75. 